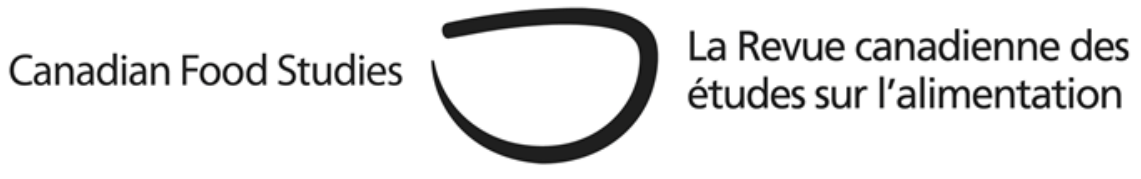

Original Research Article

\title{
Working for justice in food systems on stolen land? Interrogating food movements confronting settler colonialism
}

Michaela Bohunicky ${ }^{a^{\star}}$ Charles Z. Levkoe ${ }^{a}$ and Nick Rose ${ }^{b}$

a Lakehead University

b Williams Angliss Institute

\section{Abstract}

The evolving practice and scholarship surrounding food movements aim to address social, political, economic and ecological crises in food systems. However, limited interrogation of settler colonialism remains a crucial gap. Settler colonialism is the ongoing process that works to systematically erase and replace Indigenous Peoples with settler populations and identities. While many progressive and well-intentioned food movements engage directly with issues of land, water, identity, and power, critics argue they have also reified capitalism, white supremacy, agro-centrism and private property that are central to the ongoing dispossession of Indigenous Peoples. Scholars and advocates have called for greater accountability to the contradictions inherent in working towards social and ecological justice on stolen land. We write this paper as three settler activist-scholars to interrogate ways that social movements are responding to this call. A community-engaged methodology was used to conduct semi-structured interviews with individuals working in settler-led food movement organizations in northwestern Ontario, Canada and in southern Australia. We present our findings through three intersecting categories: 1) Expressions of settler inaction; 2) Mere inclusion of Indigenous Peoples and ideas; and, 3) Productive engagements that confront settler colonialism. To explore this third category in greater detail, we suggest a continuum that moves from situating our(settler)selves within the framework of settler colonialism to (re)negotiating relationships with Indigenous Peoples to actualizing productive positions of solidarity with Indigenous struggles. 
We argue that this work is essential for food movements that aim to transform relationships with the land, each other, and ultimately forge more sustainable and equitable food futures.

Keywords: Australia; Canada; food movements; Indigenous food sovereignty; settler colonialism

\section{Introduction}

Food movements have had significant success in raising consciousness, critiquing, and politicizing inequities in food systems (Gottlieb \& Joshi, 2010; Holt-Giménez et al., 2018; Levkoe, 2014; Sbicca, 2015; Winne, 2010). However, limited interrogation of settler colonialism remains a crucial gap in food movement scholarship and activism. Settler colonialism is described as the ongoing process of invasion that works to systematically erase and replace Indigenous Peoples ${ }^{1}$ with settler populations and identities (Veracini, 2010; Wolfe, 2006). While many progressive and well-intentioned food movements engage directly with issues of land, water, identity, and power, critics argue they have also reified capitalism, white supremacy, agrocentrism and private property that are central to the ongoing dispossession of Indigenous Peoples (Alkon \& Mares, 2012; Borras, 2020; Lockie, 2013). Scholars and advocates have called for greater accountability to the contradictions inherent in working towards social and ecological justice on stolen land (Coté, 2016; Grey \& Patel, 2014; Indigenous Circle, 2009; Martens et al., 2020).

We write this paper as three settler activist-scholars to interrogate ways that food movements are responding to this call by sharing research that explores how social movement organizations are addressing settler colonialism in their work. We use a reflexive communityengaged research methodology to navigate these issues through co-learning and to connect our own experiences and insights with those of participants. Semi-structured interviews were conducted with individuals working in settler-led food movement organizations in orthwestenrn Ontario, Canada and across southern Australia (encompassing the states of Western Australia, South Australia, and Victoria). This research is part of the Food: Locally Embedded, Globally Engaged (FLEdGE) project and speaks directly to the FLEdGE Good Food Principle of Indigenous Foodways. This principle calls for the support of "Indigenous food sovereignty by safeguarding traditional foodways that rely on the health of the land and intergenerational knowledge sharing supported by technologies, capacity, and infrastructure" (see fledgeresearch.ca).

\footnotetext{
${ }^{1}$ In this paper we use the term "Indigenous Peoples" to refer to the diverse set of people and groups that are the original inhabitants of specific places and maintain distinct cultures, languages, practices, institutions, and relationships with the lands in contrast to peoples who have colonized and/or settled those lands. In the context of Canada, the term Indigenous is inclusive of First Nations, Inuit, and Métis Peoples, and in Australia, it is inclusive of Aboriginal and Torres Strait Islander Peoples.
} 
We present the findings through three intersecting categories that synthesize participants' experiences and observations: 1) Expressions of settler inaction; 2) Mere inclusion of Indigenous Peoples and ideas; and 3) Productive engagements and visions to confront settler colonialism. To explore the possibility of deeper engagements that confront settler colonialism, we suggest a continuum that moves from situating our(settler)selves within the framework of settler colonialism to (re)negotiating relationships with Indigenous Peoples to actualizing productive positions of solidarity with Indigenous struggles. We use the concept of "confronting" to encompass the process of acknowledging, learning, and interrogating as a prerequisite to addressing, dismantling, and decolonizing. In order to meet their aspirational goals around ecological sustainability and social justice, settler-based food movements must confront settler colonialism. We argue that this involves dynamic, place-based engagements through which settlers overcome fragility ${ }^{2}$ and inclusion of Indigenous Peoples that primarily benefits settlers and fails to redistribute power. Through this central argument, we help advance an understanding of how food movement actors are furthering their understanding of and addressing settler colonialism. We also contend that this work does not fit into simple binary categories of "success" and "failure" but is found somewhere in the space between, where focus lies less on conventional measures of institutional impact but on relationality, contestation, and imagination (Haiven \& Khasnabish, 2013). This work is an ongoing, collaborative process grounded in relationships of reciprocity, discomfort and uncertainty (Davis, Denis, \& Sinclair, 2017; Regan, 2011; Sium et al., 2012; Tuck \& Yang, 2012).

\section{Context}

In this section we trace the entanglement of settler colonialism through food systems, how food movements have (and have not) attended to such issues, and the guidance that can be garnered from Indigenous food sovereignties.

\section{The ongoing role of settler colonialism in shaping food systems}

Control of land is the irreducible element and primary motivation of the settler project, where land is taken from Indigenous Peoples through direct and indirect force (Lowman \& Barker, 2015). In settler states, this political, social, and cultural structure forms the basis of personal and collective identities as well as institutions (Alfred, 2009), and is upheld through individuals' choices, mentalities, consent and active participation (Barker, 2009).

\footnotetext{
${ }^{2}$ Dina Gilio-Whitaker (2018) describes settler fragility as "the inability to talk about unearned privilege" of living on lands violently and unjustly taken on the premise of white supremacy and genocide disguised as democracy.
} 
For this article, we use Barker's (2009, p. 328) definition of settler to encompass "peoples who occupy lands previously stolen or in the process of being taken from their Indigenous inhabitants or who are otherwise members of the 'Settler society,' which is founded on co-opted lands and resources." 3 Settler is intended to be a critical, relational term that "denaturalizes and politicizes the presence of non-Indigenous people on Indigenous lands," forcing the acknowledgment of ongoing contributions to the colonial project (Flowers, 2015). Settler colonialism is thus both historical and contemporary, structuring the past, shaping the present, and conditioning the future. Tuck \& Yang (2012) discuss settler moves to innocence, described as convenient acts by settlers that absolve feelings of guilt and complicity without promoting meaningful alliances and transfers of power with Indigenous Peoples. In this paper, we use the term settler to emphasize active responsibility and complicity rather than a static, homogenous, and performative privilege (Jafri, 2012; Lawrence \& Dua, 2005; Smith, 2014; Tuck \& Yang, 2012).

The project of settler colonialism, that works through the legitimation and normalization of settler occupation of Indigenous lands, is at the heart of the dominant food system. In other words, settler colonialism is inherently enmeshed in the capitalist food systems' exploitation of land, water, and identity and through uncritical investments in private land ownership, industrial food production and harvesting, and nutrition and health science, along with the logics and institutions that sustain them (Kepkiewicz \& Dale, 2018; Mosby, 2013). Dispossession of Indigenous Peoples and their food systems is enacted through settler colonial constructions such as political borders and jurisdictions, treaties, and reserves; assimilationist policies rooted in state legislation; discriminatory policies such as residential schools and bans on ceremonies, gatherings, and protocols related to traditional food practices; the patriarchal redirection of women's roles to the home; privatization of Indigenous land for varied urban and rural development purposes (e.g., "cottage colonization"); and privatization and environmental contamination through extractive resource industries (Daigle, 2019). ${ }^{4}$ Each of these colonial and capitalist processes profoundly ruptures the complex web of land- and place-based relationships central to Indigenous cultures and nationhood (McFarlane \& Schabus, 2017; Morrison, 2011).

\footnotetext{
${ }^{3}$ For examples of perspectives of the inclusion of Black people and people of color under the label "settler" see: Jafri (2012); Lawrence \& Dua (2005); Morgan (2019); and Phung (2011).

${ }^{4}$ We refer to these examples of settler colonial constructions with recognition that there are a diversity of Indigenous traditions and aspirations that intersect with such constructions. For example, some Indigenous cultures have strong symmetries to Western constructions of agriculture and private property (Anderson, 2016).
} 


\section{Food movements and settler colonialism}

The burgeoning field of Settler Colonial Studies and critical literature on Indigenous-settler alliances and solidarity highlight an underserved and problematic relationship between Indigenous struggles and settler-based movements for social and environmental justice (Davis, 2010; Davis, Denis, \& Sinclair 2017; Fortier, 2017a; Indigenous Action, 2014; Kluttz et al., 2020; Wallace, 2013).

For example, Fortier (2017a) critiques the coalescence of decolonization with other liberatory struggles in settler colonial contexts by examining the contradictions inherent in social movements that seek to reclaim the commons on stolen land (e.g., the Occupy movement). These critiques resonate closely with the politics, discourses, and practices of food movements. Food movements can be described as networks of networks - collaborative efforts across sectors, scales, and places with collective goals to achieve more healthy, equitable, and sustainable food systems (Levkoe, 2014). There has been much progress within food movement scholarship in articulating and critiquing various social, economic, and ecological implications of the capitalist food system, including contributions to the climate crisis, exploitation of workers, and racialized and gender-based oppressions (Holt-Giménez et al., 2018; Sbicca, 2015; Winne, 2010). While critical perspectives have become well-established in food movement scholarship (Alkon \& Agyeman, 2011; Gottlieb \& Joshi, 2010; Guthman, 2008; Slocum, 2007), far fewer accounts consider settler colonialism as a framework to interrogate food systems (some exceptions include Bradley \& Herrera, 2016; Etmanski, 2012; Mayes, 2018; Rotz, 2017).

Critical scholarship has traced the enforcement of settler colonial logics on Indigenous Peoples, their lands and food systems (for examples in Canada, see Daschuk, 2013; for Australia, see Mayes, 2018; Pascoe, 2018). However, only recently have important critiques emerged regarding ongoing settler colonialism in contemporary food movement practice and scholarship. This has included limited interrogation of settler privilege, responsibility, and complicity, and a failure to understand the intersecting structures that support settler colonialism such as patriarchy and white supremacy (Etmanski, 2012). Mayes (2018) points to settler colonialism as a major omission of food movements, resulting both in a failure to achieve their goals and the active reproduction of the very conditions they seek to challenge. For example, Kepkiewicz and colleagues (2015, p. 99) problematize movements' approaches towards the inclusion of marginalized groups as an example of well-intended settler action that fails to dismantle oppressive structures and redistribute power, reminding us that "no justice can happen on stolen land.” Similarly, Grey \& Newman (2018) discuss the appropriation of Indigenous gastronomy as part of a broader strategy promoting liberal conceptions of multiculturalism, a process they call "culinary colonialism" (p. 2). They consider gastronomy as a contemporary colonial frontier and argue that refusal, or "mindful withholding" (p. 15) of Indigenous food and cuisine from the mainstream can itself be an act of resistance and resurgence. 
These critiques of inclusion contribute to a broader denouncement of the framework of statecentric inclusion and recognition to reconcile settler-Indigenous relations through settlerimposed and settler-controlled systems (Coulthard, 2014; Maddison \& Brigg, 2011; Snyder, 2019). These gaps in food movements highlight a need to better acknowledge and address settler colonialism, including assumptions and expectations of when and how Indigenous Peoples and their food systems engage or disengage with settler-based food systems.

While food sovereignty discourse and practice aim to directly address power and control in food systems (Patel, 2009), the manifestations of the movement in the global north face a host of constructive critiques in relation to Indigenous struggles in settler colonial contexts. Food sovereignty originally emerged as part of an anti-capitalist project that sought the transformation of social relations including land access, protection, and redistribution (Desmarais, 2007; Tilzey, 2019). We center food sovereignty not because it was unanimously espoused by the movements represented by the participants (though it was by some), but because we see it as an encouraging approach for confronting settler colonialism. However, in a settler colonial context we must ask: access and redistribution for whom, protection from what, and control by who? Land and property relations are often considered primarily in the context of settler access and ownership and not in relation to illegitimate occupation and appropriation of Indigenous land through public and private property regimes (Kepkiewicz, 2020; Kepkiewicz \& Dale, 2018). Further, the meaning of sovereignty itself must be re-examined, as Indigenous Peoples have distinct understandings of jurisdiction (Grey \& Patel, 2014; Moreton-Robinson, 2015; Pasternak, 2017; Simpson, 2014). This suggests that Western notions of sovereignty be extended or reframed to include "Indigenous people's struggles for autonomy, self-sufficiency, and self-determination rather than within assertions of domination, control, and authority over ancestral homelands" (Coté, 2016, p. 9). Such critiques highlight that Indigenous Peoples in the global north have not seen their values and visions reflected in the food sovereignty movement (Desmarais \& Wittman, 2014). This signals a need for food sovereignty movements - and food movements more generally - to embrace a process of unsettlement through interrogating and (re)centering relationships with Indigenous Peoples and land, and ultimately construct new, place-based notions and practices of solidarity (Davis, 2010; Davis, Hiller, et al., 2017; Fortier, 2017a; Indigenous Action, 2014; Kluttz et al., 2020; Wallace, 2013).

\section{The contributions from Indigenous food sovereignties}

Indigenous food sovereignty is a burgeoning field of scholarship that captures a diversity of theoretical and everyday expressions (Cidro et al., 2015; Daigle, 2019; Indigenous Circle, 2009; Kamal et al., 2015; Martens, 2015; Morrison, 2011; Rudolph \& McLachlan, 2013; Whyte, 2018). While its acceptance and use vary, some suggest that Indigenous Peoples have embodied food sovereignty since time immemorial (Daigle, 2019; Morrison, 2011). 
Indigenous food sovereignty is inextricably linked to broader processes of resistance to ongoing settler colonialism, as well as Indigenous cultural, social, and political resurgence (Daigle, 2019; Grey \& Patel, 2014). According to the Indigenous Circle (2009) of Food Secure Canada that guided the People's Food Policy Project, current Indigenous food sovereignty efforts "continue to be linked to the historic claims to the hunting, fishing, and gathering grounds in their respective traditional territories" (p. 4) and foster ongoing connections "between the traditional and the contemporary, the urban and rural" (p. 8). Though explicitly for and by Indigenous Peoples, Indigenous food sovereignties and other land-based expressions of Indigenous resistance and resurgence offer guidance for settler-based food movements that not only wish to avoid undermining Indigenous efforts but actively support them. This entails embracing relationships to land and place that are not predicated on erasure, exploitation, and appropriation (Kepkiewicz \& Dale, 2018; Langton, 2006; Martens, 2015; Townsend et al., 2009); supporting inherent and treaty rights and responsibilities that uphold traditional food practices on traditional lands (Grey \& Newman, 2018; Morrison, 2011); decentering settler notions and expressions of sovereignty while re-centering the diverse perspectives of Indigenous authorities, women, youth, and Elders, as well as queer, trans, and two-spirited people (Daigle, 2019); adopting a decolonizing and feminist framework (Bradley \& Herrera, 2016; Maddison \& Brigg, 2011); and being accountable to the immeasurable economic and ecological restitution owed to Indigenous Peoples (Grey \& Patel, 2014).

Importantly, Indigenous food sovereignties have been taken up by national-level food movements such as the People's Food Policy Project (PFPP, 2011) in Canada and the People's Food Plan (AFSA, 2013) in Australia. At regional scales, it has been adopted by the Indigenous Food Circle (IFC) in Thunder Bay, Ontario (Levkoe et al., 2019a) and the BC Food Systems Network in British Columbia (Morrison \& Brynne, 2016), which serve as examples of those working to unsettle and decolonize food movement work. These examples suggest that some food movements are taking settler colonialism more seriously in their attempts to build equitable and sustainable food systems by embracing experiences and insights from Indigenous activists. Confronting settler colonialism is an essential step in this process. In the next section, we turn to our research findings that interrogate the efforts of settler-led food movement organizations in northwestern Ontario and southern Australia.

\section{Methodology and methods}

The approach to our research was informed by settler colonial studies, as well as Indigenous and decolonizing research methodologies, particularly the demands and critiques of anti-colonial and decolonizing settler scholarship. These include decentering settler perspectives wherever possible; seeking complementary frameworks that offer alternatives to settler colonialism (such as decolonization); interrogating social justice approaches to anti-colonial action; taking an intersectional approach; grounding work in long-term, reciprocal, place-based relationships; 
sharing Indigenous perspectives with other settlers in non-appropriative ways; naming Indigenous influences; practicing critical self-reflexivity; and remaining attentive to the inherent limitations of settler subjectivities (Carlson, 2017; Fortier, 2017b; Macoun \& Strakosch, 2013; Snelgrove et al., 2014). We come to this research as three settler activist-scholars with an aim to explore ways that food movements are responding to the challenges and criticisms of practicing and theorizing social and ecological justice on stolen land. We acknowledge and take responsibility for the many risks, contradictions, and limitations inherent in this work; we embrace these tensions and commit ourselves to the messiness, discomfort, and critique this work entails. We also acknowledge that we are navigating these issues alongside the research participants, and because of the co-learning opportunities yielded by the community-engaged approach to this research, our analysis of participants' perspectives cannot be easily separated from our own. Thus, this paper embraces the interconnections between scholarship and activism and the blurred subjectivity between researcher and researched (Reynolds et al., 2018; Levkoe et al., 2019b), as well as convergence between our findings and analysis.

Semi-structured interviews were conducted with representatives from settler-led food movement organizations in northwestern Ontario, Canada and in Western Australia, South Australia, and Victoria, Australia. Interview questions centered on past and current organizational confrontations of settler colonialism; relationships with Indigenous communities and support of Indigenous food sovereignty; the perceived successes and tensions, motivations and aspirations; and structural factors such as organizational model or policy. Participants were recruited through two food movement network organizations, Sustain: The Australian Food Network (Sustain) and the Thunder Bay and Area Food Strategy (TBAFS). Nick Rose is the Executive Director of Sustain and Charles Levkoe serves as an executive member for the TBAFS; both engaged in the research process through participating in conceptual discussions and supporting the data analysis and writing. Michaela Bohunicky conducted field work in Australia in July-September 2019 and in Ontario in September-December 2019. Purposeful and snowball sampling was used to recruit individuals and organizations that were interested in or actively addressing issues of settler colonialism through food systems work. This consisted of representatives from non-profit organizations, government departments including public health and city councils, academics, and private business. Twenty-three participants were settlers and the remaining four were Indigenous community leaders with experience partnering with settlerbased organizations (three were based in southern Australia, one in Thunder Bay). The decision to interview primarily settlers was an attempt to take ownership of settler responsibilities but comes at the risk of (re)centering settler voices (Fortier, 2017b) and excluding Indigenous counter-narratives that could lend key insights and critique to settler perspectives. To counter this, our analysis (and the research process more generally) has been informed by the voices of four Indigenous participants, Indigenous scholars and activists, and our own experiences and relationships in our respective food movements. The findings and discussion in particular were guided by the voices of the Indigenous participants. Ten participants were interviewed in Ontario and 17 in Australia. 
In the presentation of the findings, we anonymized all settler participants and described individuals by their respective sector and (where appropriate) organizational position. The two identified participants are Indigenous community leaders that requested to have their names attached to their words. Interviews were transcribed and coded using NVivo software. A thematic approach to qualitative data analysis resulted in three emergent themes that describe various ways in which participants and their organizations were engaging in issues of settler colonialism. While we recognize the many important distinctions between the Canadian and Australian contexts, including differences in size and remoteness across research sites, data collection was not extensive enough in each region to provide comparisons within this paper (though we recognize the opportunity and need for comparative studies as part of future research). Thus, we have combined the data analysis and present the findings together. By doing so, we hope to emphasize the process-based nature of this work while remaining mindful that these processes are context-specific. Conducting this research with food movement organizations in two settler states with similar, yet distinct colonial contexts presents an opportunity for these movements to learn from and with each other.

\section{Northwestern Ontario, Canada}

Northwestern Ontario encompasses over half of the province's land mass and is located northwest of Lake Superior, to the east of Manitoba and the west of James Bay. It sits on the Traditional Territory of the Anishinaabe Peoples of the Robinson-Superior Treaty (1850), Treaty 3 , Treaty 5, and Treaty 9. Thunder Bay is the region's largest city with a population of about 110,000 (over half the region's population) and serves as a regional hub for health care and social services, retail food businesses, and other basic amenities. While the settler population is primarily of European and Scandinavian origin, Indigenous Peoples make up almost 13\% of the city's population, the highest proportion of urban Indigenous Peoples in Canada (Statistics Canada, 2017). ${ }^{5}$ There are also dozens of First Nations groups located throughout Northwestern Ontario, each with their own governance systems, histories, and cultures. Food movement activity in the region has been significant. For example, years of community engagement by members of the TBAFS contributed to the emergence of the IFC in 2017. The IFC aims to use food as a tool for reconciliation and resurgence through strengthening the fabric of Indigenousled organizations in the Thunder Bay area, providing a space to develop Indigenous-led and decolonized solutions to food systems issues, and forge relationships between Indigenous-led and settler-led organizations (Levkoe et al., 2019a).

\footnotetext{
${ }^{5}$ A recent study coordinated by Anishnawbe Mushkiki suggests the population of Indigenous people may be more three times higher than Statistics Canada data indicates (Smylie, 2021).
} 


\section{Southern Australia (Victoria, South Australia, and Western Australia)}

The research conducted in Australia involved members of organizations working in the cities of Melbourne and Bendigo (Victoria), Adelaide (South Australia), and the region to the southwest of Perth (Western Australia). Nearly $60 \%$ of Australia's Indigenous population lives in the states of New South Wales and Queensland, with Victoria (7\%), South Australia (6\%) and Western Australia (13\%) accounting for less than 30\% together (ABS, 2019). Melbourne is Australia's second-largest city, with a population of 5,200,000. The city was founded as a British settlement in 1838, on the lands of the Wurundjeri-Woiwurrung, the Bunurong, and the Boonwurrung nations. Adelaide's population is 1,430,000, making it Australia's fifth largest city. It was settled in 1836, on the lands of the Kaurna and Peramangk nations. Perth has a population of 2,000,000, making it Australia's fourth largest city. It was established in 1829, on the lands of Wajuk nation, with the region south of Perth comprising the lands of Amangu, Yued/Yuat, Whadjuk/Wajuk, Binjareb/Pinjarup, Wardandi, Balardong/Ballardong, Nyakinyaki, Wilman, Ganeang, Bibulmun/Piblemen, Mineng, Goreng and Wudjari and Njunga (ABS, 2019; AIATSIS, 2020). Together these 14 language groups are known as the Noongar Peoples, one of the largest Indigenous cultural and geographic blocks in Australia. Settler-led food movement activity in Australia has had a strong focus on typical expressions of other local food movements in the global north, such as community gardening, farmers markets, community supported agriculture and school garden programs. Organizations working across these and related fields are active in all three of the study areas. In recent years there has been a cohesive push in Western Australia towards regenerative agriculture. Due in large part to the scholarship and advocacy of settlerfarmer Charles Massy (2017), the work of the University of Western Australia's Centre for Social Impact (CSI), Noongar elders, and others, dialogue has commenced with Noongar-led organizations and food movement groups in Perth and the southwest of Western Australia. A significant moment in this dialogue occurred with the Danjoo Koorliny Walking Together Towards a Just and Sustainable Society, a CSI-held Social Impact Festival from 15-20 July 2019. ${ }^{6}$ This festival was designed and led by Noongar elders Dr. Noel Nannup, Dr. Richard Walley, Professor Colleen Hayward, and Carol Innes with the aim of 'embracing the spirit of Voice, Treaty and Truth' as the $200^{\text {th }}$ year of colonization in Perth (2029) approaches.

\footnotetext{
${ }^{6}$ See https://www.csi.edu.au/news/voice-treaty-and-truth-walking-together-create-new-social-impact-festival/ and http://www.kelvybird.com/danjookoorliny/.
} 


\section{Findings}

In this section, we present the research findings through three emergent themes: 1) Expressions of settler inaction; 2) Mere inclusion of Indigenous Peoples and ideas; and 3) Productive engagements and visions to confront settler colonialism. It is important to note that most participants spoke to multiple themes and thus their responses did not fit neatly into one category.

Considering our choice to use the terminology of settler colonialism in this project, settler participants' reactions to its uses and underlying meanings are noteworthy. This was not part of the initial interview questions but consistently came up in almost all of the conversations. Many admitted that settler colonialism was not a term they had used or were even familiar with prior to receiving the interview request (however, the term colonialism was more familiar). Some participants agreed that "settler" was an important and useful term, while others felt less comfortable with its use.

For example, one participant felt it was overly "academic" and not "tangible to people doing this work on the ground," while another preferred to think of their engagement with these issues as a "constantly evolving understanding of cultural heritage as it relates to Indigenous people." One participant expressed frustration with the divisiveness of labels such as settler/Indigenous and colonized/colonizer, arguing that everyone had all been colonized at some point in history and that there was a need for more constructive ways to relate to one another. We further explore the expressions of these terminologies through the findings and proceeding section.

\section{Expressions of settler inaction}

Participants agreed unanimously that confronting settler colonialism was important. However, many barriers were identified, often leading to or perpetuating inaction. In this section, we outline immobilizing factors relating to fears of upsetting Indigenous Peoples, fears of confronting other settlers, real and perceived capacities of Indigenous groups, and institutional limitations. We conclude with a description of participants' motivations to do this work.

Several identified barriers centred on a fear of upsetting Indigenous Peoples. Many participants spoke of a reluctance to engage in the process of confronting settler colonialism due to a fear of making mistakes such as not knowing proper protocols and teachings and not having guidance regarding where and how to engage. For example, two participants - one, a regional government worker and the other involved in research and education - said it was not until they formed a personal relationship with an Indigenous knowledge holder and received teachings that they felt comfortable performing and customizing land and country acknowledgements. ${ }^{7}$

\footnotetext{
${ }^{7}$ Land acknowledgements (as they are commonly referred to in Canada) and acknowledgments of country (Australia) are often made to open gatherings and are intended to recognize and pay respect to specific Indigenous nations' histories, cultures, and contributions to the area the gathering is taking place in, as well as the settler
} 
They described the tension of not wanting to seem passive or tokenistic by reading the acknowledgement of country word for word, but also did not want to risk blundering something so important by going off script. In another instance, a city councillor spoke of settlers' hesitance in using local Indigenous language at community events, even though it is encouraged by the local Indigenous nation. Within the city council, they added, it is easy (and common) for people to offload engagement on a colleague they believe has more knowledge, experience, or willingness. Another participant who works in public health likened their hesitation to advocate on behalf of First Nations to the broken telephone game, where the message gets increasingly distorted as it gets whispered from person to person.

Concerns were also raised among participants reportedly self-censoring themselves in anti-colonial messaging to avoid creating discomfort for other settlers.

For instance, one participant who sits on a food policy council expressed that with recent member turnover and diverging views on colonialism, the space has not felt safe enough to broach the subject; they feared that calling people out could shut communication down at a time when teambuilding was imperative. In their encounters with settler farmers expressing antiIndigenous views, a government worker in the agricultural sector reasoned: "It can be difficult, but it's not for me to fight battles... sometimes I just back off from being involved if I think that it could go badly." This speaks to a misalignment between organizational values and accountability among settlers in support of Indigenous Peoples. If settlers are not driven to engage in difficult conversations within their immediate work relationships, what does that mean for movement-wide efforts to address settler colonialism?

Several participants referred to barriers related to the perceived capacities of Indigenous groups. For example, some Indigenous groups were seen as inundated with engagements with settler organizations; so much so, according to one government employee, that sometimes settler groups forego attempts to engage entirely. This perceived lack of capacity was criticized by another participant, a city councillor, for being infantilizing, weakness-based, and born out of a colonial framework. Participants in multiple geographical locations also expressed uncertainty in navigating engagement in situations of conflict between Indigenous groups such as contested land or competition for government-granted status. The same government worker said this dilemma causes them to sometimes step back from engagement entirely: "There are times where you have to just step away because it's not for us to be involved in that contested relationship... We literally just don't get involved in any of the political side of things." This form of inaction may be suggestive of settler fragility and bias, and of deeply systemic tensions with no simple solutions.

Nearly every participant described facing institutional barriers and expressed doubts regarding institutions' capacities to address settler colonialism.

colonial impacts. In Australia, an acknowledgement of country is different from a welcome to country; while an acknowledgement of country can be performed by Indigenous and non-Indigenous people, only Indigenous Elders can welcome people to country. 
Many reported facing a lack of capacity within their daily work because it was not technically part of their portfolio and it sits perpetually on the side of their desk, crowded out by daily operations and larger projects. Participants working in public health also reported juggling accountability to parties with competing priorities, namely the provincial government and community partners. This tension has become especially obvious in Indigenous food sovereignty projects where advocates continuously bump up against the structures that govern these institutions. For example, provincial funding requirements make it extremely difficult for public health to relinquish full decision-making authority to community partners, evading the power redistribution required for Indigenous food sovereignty. Competing values and priorities have also been evident in efforts to support some of the Indigenous-led initiatives like access to wild game, where jurisdictional issues between different levels of governments, as well as public health directives have been a major challenge.

Participants in the non-profit sector identified specific barriers in doing work to address settler colonialism. These challenges primarily centered on having no core funding and only short-term grants for staffing and programming.

This limits institutional memory and longer-term impact in the community, according to one participant. Multiple participants described being too busy maintaining daily operations, as well as "two-stepping" around entrenched systems to attend to strategic, longer-term work. While there are positive steps organizations can take, one participant added, they remain nested within a much larger model that they don't see changing for decades to come: "Until that bigger structure changes, it feels as though the movement is really, really slow. I know change has to happen on both levels, but it sometimes feels really hard to do that within the structure that we live in."

Some participants referred to confronting settler colonialism as an ethical or moral obligation to resolve a shameful, unresolved history. For example, one participant suggested, that unless we see settler colonialism as a foundational tenet of oppression, "we're always going to be working downstream. We're always going to be needing a foodbank, yelling at the government to increase minimum wages. We're always going to be looking at this from a catch-up position instead of addressing the cause." These obligations at times were expressed in political commitments such as support for the United Nations Declaration on the Rights of Indigenous Peoples (UNDRIP), Treaties between the Crown and Indigenous leaders, and public health research and practice mandates. Participants were also motivated by the growing failure of Western systems, the false legitimacy of settler sovereignty and identity, and the belief that addressing settler colonialism helps recover more sustainable and peaceful ways of living that can inform collective futures. There was also a strong acknowledgement that food systems work is embedded within settler colonialism, most prominently through issues related to land that remain glaringly absent from food movement discourse. 


\section{Mere inclusion of Indigenous Peoples and ideas}

While participants described barriers to engagement, they also shared many examples where these challenges had been overcome. These were instances where organizations had made conscious efforts to embrace the inclusion of Indigenous Peoples and ideas. However, participants were quick to problematize such attempts and approaches of inclusion in that they primarily benefit settlers and fail to redistribute power. It is important to note that many of these instances of inclusion are founded in goodwilled intentions by settlers and an excitement to learn about and be a part of Indigenous-led efforts. Bruce Pascoe, an Aboriginal Australian writer and author of the bestselling non-fiction book Dark Emu that examines the history of Aboriginal agriculture, talked about his frustration with enthusiasm that stops short of action. Pascoe noted that this has especially come up when invited to take part in various festivals, meetings, and other spaces brimming with settler emotion:

Excitement is a wonderful thing, but action as a result of excitement is the real crux. I can see the excitement. I'm surrounded by it... Just because you're excited doesn't mean to say that's going to be enough. We have to change the way the country operates... Not this gushy excitability. It's not enough. And it infuriates me. I was suspicious of it when it began and I'm more suspicious of it now because that's all that's happened.

Pascoe added that both government and philanthropic organizations are guilty of this kind of lip service: "All talk, all excitement, all want to be in on that bandwagon, to say they're supporting Aboriginal communities. Well don't say it if you haven't already done it." Notably, Pascoe's work was mentioned by nearly every Australian participant.

The flipside to settler excitement is that it can also lead to further dispossession through inclusion. Referring to the ways Western researchers have been part of these problematic processes, a university professor explained, "The risk going forward is that people like me will get really excited by Bruce Pascoe's work, pick it up, and just kind of run off and do the white thing with it." An Indigenous bush food ${ }^{8}$ business owner elaborated on the inherent risk of sharing work such as Pascoe's: "That's great now you've made everyone aware of [the history of Aboriginal agriculture]. But what are you doing to protect that information for our communities, because you've just released Pandora's box... If we highlight this, we have a responsibility then to make sure we are protecting it." Several participants mentioned Australia's bush food industry as a salient example of exploitation of Indigenous food systems, marked by a recent surge of settler enterprises appropriating and capitalizing on the nutritional, culinary, pharmaceutical, naturopathic, horticultural, and tourism opportunities of Indigenous bush foods.

\footnotetext{
${ }^{8}$ Bush foods, also known as bush tucker, refers to plant foods native to Australia.
} 
Ongoing research suggests only $1 \%$ of the industry is owned or controlled by Indigenous Australians (Mitchell \& Becker, 2019). This issue is not simply one of market competition but structural discrimination towards Indigenous economic development and land ownership and access, and thus clearly expressive of ongoing settler colonialism in Australia.

Collective spaces that allow settlers to connect with and learn from Indigenous Peoples were seen as a powerful way to harness excitement and ultimately ease settler ignorance. However, participants argued that this could also be problematic by placing unfair emotional demands on Indigenous partners and limits the capacity for productive alliance-building. This is precisely what Jessica McLaughlin, coordinator of Thunder Bay's IFC experienced. As it gained settler membership (representatives from settler-led, Indigenous-serving organizations), gaps in settler understanding of colonialism and readiness became increasingly apparent in meetings, causing many Indigenous members to express concern or stop showing up. Examples include settlers becoming fragile or emotional and diverting attention away from the collective agenda. "You can listen to me spew and sound like an angry Indian, but at the end of the day it's up to you to unpack [settler colonialism] yourself," she said.

Participants also voiced concerns over the emotional labour demanded from Indigenous partnerships, relations and board positions, the offloading effect they can have on settler accountability, and their often siloed, tokenistic and precarious nature.

McLaughlin described her own experience in these positions as isolating, awkward, and painful, especially without settler allies. It is important to note that other settler participants applauded these institutional practices of inclusion. For instance, one participant working for a regional government in agriculture and land care spoke about the many benefits of having an Indigenous facilitator (hired through a federal grant): "It's been key...We could ask all sorts of dumb questions, or ignorant questions and he would be willing to answer them knowing that in the process, he's educating us on the right and wrong way to go about things." These expressions raise important questions about the kinds of additional responsibilities that might be placed onto settlers to offload unnecessary emotional labour from Indigenous individuals in leadership positions.

Other seemingly positive institutional practices of inclusion such as supportive policy, partnerships, working groups, and staff training were criticized by some participants as being ineffective institutional checkboxes that fail to change power relations between Indigenous and settler peoples or promote awareness among settlers of unequal power relations. For example, in one institutional partnership between a city council and an Indigenous community seeking special heritage status, a strong emphasis of Indigenous food systems in the bid was included with the objectives of strengthening Indigenous-settler relationships, promoting the region's "true story," and creating a coordinating mechanism across various food efforts in the region. However, a participant involved in the bid expressed concerns over tokenism and the Council's "renewed" approach to the relationship would fail to redistribute ownership and authority: "It's always 'Come to our offices, on our terms, on our turf, with our meeting structures and our timelines'... Our whole structure has a kind of covert racism to it." 
Another way that participants reported including Indigenous voices and knowledges in food systems work was through organizational events and programming. Examples included gently weaving elements of Indigenous food systems into annual farming events over multiple years; featuring prominent Indigenous people as keynote speakers at conferences; redistributing planning authority of multi-day gatherings to Indigenous people and groups; and holding meetings with Indigenous partners on their terms. Some participants also identified opportunities to promote Indigenous knowledge through more passive educational initiatives such as gardens, urban farms, and land and waterway restoration projects. While some of these initiatives did yield positive, long-term results, others were seen as problematic in similar ways to instances mentioned above (e.g., appropriation, excitement without action, emotional labour, tokenism, and institutional checkboxes). While some settler participants deemed the actions of other settlers as problematic — at times oblivious to their own problematic actions — others directed their critique internally. For example, reflecting on hosting Indigenous youth groups on his property, a settler farmer said that programming carries uncomfortable undertones of present-day assimilation strategies and that he feels apprehensive of whether or not these efforts actually make a difference for the groups: "Is this just us trying to put on a good show? ... Who are we doing this for? Are we doing it for them or are we doing it for ourselves, so we feel better about what's happened in the past?"

\section{Productive engagements and visions to confront settler colonialism}

This third theme focuses on engagements that constitute more meaningful confrontations to settler colonialism. As this section demonstrates, confronting settler colonialism enables an engagement with other settlers in similar paths, forging new relationships with Indigenous Peoples, and eventually embodying settler responsibilities through food movement praxis, all processes described by participants as critical, life-long, mutually reinforcing, messy, and deeply unsettling. These processes can also be seen as the antitheses of processes of inaction and inclusion.

Uncovering history (one that exposes rather than conceals settler colonialism) and truthtelling was identified by many participants as an important starting place to confront settler colonialism, and as Pascoe insisted, a prerequisite to any collective conversations:

Before we even have a conversation about food or employment or education, Australia has to have the conversation with itself and with us, hopefully, about how Europeans came here and why. What they did subsequent to that. The fact that the whole of Australia and parliament is racist from day one and that there have been absolute atrocities on this land. If we can't talk about that, if we don't admit to that, we cannot have a conversation. 
Uncovering history and truth-telling was not only seen as an opportunity to learn from incredible harms committed, but also to glean insights into highly productive and harmonious Indigenous ways of life prior to European contact that have been practiced since time immemorial. In nearly every interview in Australia, Pascoe's book, Dark Emu, was described as seminal in participants' learning of Indigenous food systems and European colonization. However, as one participant reminded, spending too much time looking backwards means that "you're going to bump into the wall or the fence." Creating new visions for sustainable food systems requires more than passively learning history, but also interrogating present realities, identities and relationships with the land and Indigenous Peoples. These can be mutually reinforcing activities. For example, one non-profit organization collectively read and discussed Canada's Truth and Reconciliation Commission Report ${ }^{9}$ and identified opportunities to support the report's Calls to Action. Participants also insisted that settlers engaging in anti-colonial learning and action have a dual responsibility to support this engagement among other settlers by providing spaces for settlers to collectively process and by sharing appropriate Indigenous protocols among settler networks. A director of a community-based non-profit described this support as dispelling too-common misunderstandings and excuses:

I've sat at a lot of tables where people... think that if they don't spit at an Indigenous person that they're not a part of colonialism, and so I think my role is to do that knowledge translation... What a lot of people don't understand about this is a commitment of sharing power is difficult. It doesn't come without pain.

Supportive (settler) leadership was also seen by participants as extremely important in having the capacity to learn about and act in ways that challenge settler colonialism within their organizations, though not all felt this was a reality in their workplaces.

Participants stressed that having a basic understanding of settler colonialism allows for more productive, place-based relationships with Indigenous Peoples, and that the process of forging such relationships is uncomfortable, uncertain, slow, and messy. Pascoe comments, "We have to have that truth and reconciliation or whatever they call it. Where we call a spade a spade. It'll be deeply bruising... Being hurt and wounded and sore is part of the process." The IFC in Thunder Bay is an important example of a space where Indigenous-settler relationships are being forged. Though many challenges persist, McLaughlin stresses the importance of settler-led food organizations recognizing their power and using it to support Indigenous struggles. One settler member of the IFC echoed this sentiment, adding that supporting Indigenous struggles is not just going to meetings but is about bringing the IFC's demands back to their respective organizations and networks and fighting to secure commitment to those demands.

\footnotetext{
${ }^{9}$ In 2008, legal negotiations around the Indian Residential Schools Settlement Agreement mandated the establishment of a Truth and Reconciliation Commission (TRC) to create a space of learning, discussing, and documenting the history and impacts of the residential school system. The TRC worked from 2009-2015 and produced a series of materials available to the public, including the TRC Report (www.nctr.ca).
} 
Although all participants had already begun learning about settler colonialism in one way or another, many admitted to struggling with where and how to start acting against it. Institutional approaches envisioned by participants include unwavering commitment to Indigenous-led community partners best positioned to do this work, such as the IFC; "scaffolding" anti-colonial structures across the entire organization rather than siloed within one workshop, project, department, or position; and undergoing a structured, formalized process of articulating a position on and committing to Indigenous food sovereignty that is part of a shared effort across many organizations. One non-profit organization in particular, through a recent strategic planning process, established a priority focused on challenging colonialism. A key staff member admitted that it has taken years of organizational growth and change to start thinking about their role as a settler organization working with Indigenous groups. The work now, they explained, is figuring out what it means to operationalize the priority, a perpetually uncertain process: "I think it's messy. Like it's really messy. But I think it's being comfortable in the messiness and being comfortable in the chaoticness of it and being comfortable in the discomfort."

\section{Discussion}

The findings from our research show that when food movement organizations seek to confront settler colonialism, it is a process riddled with challenges and missteps that requires constant interrogation, critical self-reflection, and disruption. We use the concept of confronting to encompass acknowledging, learning, and interrogating as a prerequisite to addressing, dismantling, and decolonizing. Most participants in our study expressed that they were in the early stages of conceptualizing what it means to confront settler colonialism while fewer were actively articulating and embodying such commitments. In this section, we reflect on the findings to identify possibilities for food movement organizations to more deeply engage with confronting settler colonialism. We suggest these engagements as a continuum that moves from situating our(settler)selves within the framework of settler colonialism to (re)negotiating relationships with Indigenous Peoples to actualizing productive positions of solidarity with Indigenous struggles. While these processes are mutually reinforcing, we suggest that they also must, to some extent, be navigated sequentially in order to minimize further exploitation and unnecessary labour for Indigenous Peoples.

\section{Situating our (settler) selves}

McLaughlin asserted that unpacking settler colonialism should be primarily the responsibility of settlers, not Indigenous Peoples. However, a lack of understanding of settler colonialism was identified as a key challenge among participants. 
Discomfort with the implications of embracing the concept of "settler," fear of upsetting others (i.e., both Indigenous and settler people), perceptions of overstretched Indigenous groups, and the sheer complexity and deep entrenchment of settler colonialism were all factors that led to inaction and in many cases immobilization for settlers. While such feelings of discomfort, fear, and fragility are common in the process of learning and unlearning about settler colonialism, if they do not evolve into more productive forms of engagement, they effectively negate settler responsibilities and ultimately constitute moves to innocence (Davis, Hiller, et al., 2017; Kluttz et al., 2020; Lowman \& Barker, 2015; Regan, 2011; Tuck \& Yang, 2012). This is similar to feelings of excitement to support Indigenous struggles that are not adequately accompanied by action.

We also see that taking on the work of unpacking settler colonialism within settler circles offloads some of the emotional labour demanded of Indigenous people in educating settlers - $\mathrm{a}$ problematic process discussed in the next category. Further, many motivations such as being accountable to moral (social), political, environmental, and professional obligations become realized while learning about settler colonialism, propelling settlers to approach their work with new understandings or engage in different kinds of work (e.g., anti-colonial).

Indeed, until settler colonialism and its implications for land, food and sovereignty are "common parts of our lexicon," as one participant described, settlers are going to have difficulty addressing these complex challenges. However, while all participants viewed settler colonialism as deeply problematic, many framed it historically and without mention of their own complicity. For example, the settler participant who preferred to see their engagement with these issues as a "constantly evolving understanding of cultural heritage as it relates to Indigenous people" risks

naturalizing their own settler positionality which distracts from the need to turn their gaze inward on their settler-self (Jones \& Jenkins, 2008). We echo scholars that have cautioned an engagement in settler colonialism that does not emphasize its pervasiveness, intersectionality, and settler responsibility and complicity (see Coulthard, 2014; Jafri, 2012; Lawrence \& Dua, 2005).

\section{Renegotiating relationships}

For many food movement organizations, partnerships are a central site for examining and actively challenging settler colonialism. While settlers have unique and important roles in confronting settler colonialism, addressing it is a relational, collective process that cannot be done in isolation from Indigenous Peoples. However, findings show that increasingly common ways of centering and collaborating with Indigenous people use an approach of inclusion that favours settler access to Indigenous Peoples and food systems rather than supporting permanent transfers of power and ownership (for example, see Kepkiewicz et al., 2015 and Coulthard, 2014). 
We see examples of this inclusion in relationship building for the purpose of educating settlers and in the creation of Indigenous positions within organizational structures to "indigenize" the workplace. Another example is found in public health officials' reports of feeling caught between competing priorities of the government and their Indigenous community partners. This tension can become part of settler moves to innocence which supports doubts of the capacity of larger bureaucratic organizations to address settler colonialism. However, the autonomy that public health maintains as a peri-government institution carries with it the possibility of change.

In contrast, participants insisted that building authentic relationships between Indigenous and settler peoples is difficult and messy work that requires both systemic integration and unconditional commitment from settlers in asserting influence in their own settler spaces and towards settler governments to support Indigenous demands. Mississauga Nishnaabeg scholar and activist Leanne Betasamosake Simpson writes, "the alternative to extractivism is deep reciprocity. It's respect, it's relationship, it's responsibility, and it's local" (quoted in Klein, 2013). Thus, relationships between Indigenous and settler peoples are important elements of collective transformation, the viability of which we now consider in the context of food movement organizations.

\section{Actualizing organizational commitment}

Recognizing that settler colonialism is an issue at the core of food movement work, some participants have begun exploring how to articulate institutionally and embody commitments to Indigenous struggles within their organizations. However, this research demonstrates that there are few instances where this is actively being done, confirming that more work is required to articulate, enact, and propagate such commitments across scales, disciplines, and sectors. Interestingly, the most promising examples of organizational commitment in the findings were by smaller non-profit groups that are integrating anti-colonial learning and action into strategic planning and, by extension, all programs and operations. Yet, these are the organizations that felt they had very little infrastructure to do this work, with many participants demanding sweeping changes to imposing, higher-level structures such as national legislation, governance, and funding models. Many participants expressed challenges and doubts regarding organizational capacities to address settler colonialism. There were also many examples of inclusion through institutional processes and structures. As a result, food movements face difficult questions about how settler colonialism can be addressed through settler-imposed and settler-controlled systems and what they are willing to sacrifice in order to dismantle them. 


\section{Conclusion}

Settler colonialism is an ongoing process of invasion that aims to systematically erase and replace Indigenous society with settler populations. Moreover, settler colonialism has been identified as a crucial gap in the scholarship and practice of food movements. The findings from this research leave us with a number of further questions: What lies beyond settler colonialism? How can it be overcome and transformed? What would a transformed food system look like in Canada, Australia, and globally? Does confronting settler colonialism enable food movement organizations to better support Indigenous food sovereignty? These questions are vital because the tumultuous beginnings of the second decade of the $21^{\text {st }}$ century have made clear what critical food scholar-activists have expressed for some time: the dominant food system operates on the capitalist logic of the ceaseless expansion of production, consumption, and profit, and is fundamentally exploitative, wasteful, irrational, and inhumane to Indigenous Peoples and to society as a whole. John McMurtry (1999) likened capitalist expansion across civil and environmental systems to the destructive invasion and proliferation of cancer in the human body. Thus, he suggested, we have reached the cancer stage of capitalism. We argue that from a food sovereignty perspective, the work of confronting settler colonialism is necessarily imbricated with the urgent task of moving beyond the self-destructive logic of capitalism, which has always been deeply interconnected with the ongoing project of settler colonialism (Rose, 2021). By engaging in this process, food movements can commence and advance the work of building relationships of trust and solidarity between Indigenous and settler populations to co-create a shared vision of living together in harmony and respect.

In this paper, we have advanced an understanding of how food movement actors are furthering their understanding of and addressing settler colonialism through the process of confrontation. We argued that this involves overcoming a multitude of immobilizing factors so that settlers can put the time and effort necessary into both independent and collective learning, finding non-exploitative ways of building relationships with Indigenous Peoples, and exploring ways to embody dynamic, place-based solidarity through the many types of organizations represented in food movements. Though these methods of confronting settler colonialism can be mutually reinforcing, they are rarely comfortable, straightforward, or pre-determined. This work is an essential part of Indigenous food sovereignty and necessary for settler food movements in the global north that aim to transform relationships with each other, the land, and ultimately forge more sustainable and equitable food futures. Indeed, this work is urgent and must be at the core of the political project of social and environmental transformation. 
Acknowledgements: We would like to acknowledge funding contributions from Mitacs, the Social Science and Humanities Research Council of Canada, and FLEdGE (Food: Locally Embedded, Globally Engaged). We also wish to express our gratitude to Lindsay Galway, Rebecca Schiff, Peter Andree, the Sustainable Food Systems Lab group at Lakehead University, and all of the research participants for their invaluable time and insights.

\section{References}

ABS [Australian Bureau of Statistics]. (2019). QuickStats. https://www.abs.gov.au/websitedbs/D3310114.nsf/Home/2016\%20QuickStats

AFSA [Australian Food Sovereignty Alliance] (2013). The peoples'food plan: A common-sense approach to a tasy, resilient and fair food system for all Australians. afsa.org.au/wpcontent/uploads/2012/10/PFP-policy-august13.pdf

AIATSIS [Australian Institute of Aboriginal and Torres Strait Islander Studies] (2020). AIATSIS map of Indigenous Australia. Retrieved from https://aiatsis.gov.au/aboriginal-studiespress/products/aiatsis-map-indigenous-australia

Alfred, T. (2009). Wasase: Indigenous pathways of action and freedom. University of Toronto Press.

Alkon, A. H., \& Agyeman, J. (Eds.). (2011). Cultivating food justice: Race, class, and sustainability. MIT Press.

Alkon, A. H., \& Mares, T. M. (2012). Food sovereignty in US food movements: Radical visions and neoliberal constraints. Agriculture and Human Values, 29(3), 347-359. https://doi.org/10.1007/s10460-012-9356-z

Anderson, T. L. (2016). Unlocking the wealth of Indian nations. Lexington Books.

Barker, A. J. (2009). The contemporary reality of Canadian imperialism: Settler colonialism and the hybrid colonial state. American Indian Quarterly, 33(3), 325-351.

Borras, S. M. (2020). Agrarian social movements: The absurdly difficult but not impossible agenda of defeating right-wing populism and exploring a socialist future. Journal of Agrarian Change, 20(1), 3-36. https://doi.org/10.1111/joac.12311

Bradley, K., \& Herrera, H. (2016). Decolonizing food justice: Naming, resisting, and researching colonizing forces in the movement. Antipode, 48(1), 97-114.

https://doi.org/10.1111/anti.12165

Carlson, E. (2017). Anti-colonial methodologies and practices for settler colonial studies. Settler Colonial Studies, 7(4), 496-517. https://doi.org/10.1080/2201473X.2016.1241213 
Cidro, J., Adekunle, B., Peters, E., \& Martens, T. (2015). Beyond food security: Understanding access to cultural food for urban Indigenous people in Winnipeg as Indigenous food sovereignty. Canadian Journal of Urban Research, 24(1), 24-43.

https://cjur.uwinnipeg.ca/index.php/cjur/article/view/9

Coté, C. (2016). "Indigenizing” food sovereignty: Revitalizing Indigenous food practices and ecological knowledges in Canada and the United States. Humanities, 5(57), 1-14. https://doi.org/10.3390/h5030057

Coulthard, G. (2014). Red skin, white masks: Rejecting the colonial politics of recognition. University of Minnesota Press.

Daigle, M. (2019). Tracing the terrain of Indigenous food sovereignties. The Journal of Peasant Studies, 46(2), 297-315. https://doi.org/10.1080/03066150.2017.1324423

Daschuk, J. (2013). Clearing the plains: Disease, politics of starvation, and the loss of Indigenous life. University of Regina Press.

Davis, L. (2010). Alliances: Relenvisioning Indigenous-non-Indigenous relationships. University of Toronto Press.

Davis, L., Denis, J., \& Sinclair, R. (2017). Pathways of settler decolonization. Settler Colonial Studies, 7(4), 393-397. https://doi.org/10.1080/2201473X.2016.1243085

Davis, L., Hiller, C., James, C., Lloyd, K., Nasca, T., \& Taylor, S. (2017). Complicated pathways: Settler Canadians learning to re/frame themselves and their relationships with Indigenous peoples. Settler Colonial Studies, 7(4), 398-414. https://doi.org/10.1080/2201473X.2016.1243086

Desmarais, A. (2007). La Via Campesina: Globalization and the power of peasants. Fernwood.

Desmarais, A. A., \& Wittman, H. (2014). Farmers, foodies and First Nations: Getting to food sovereignty in Canada. The Journal of Peasant Studies, 41(6), 1153-1173. https://doi.org/10.1080/03066150.2013.876623

Etmanski, C. (2012). A critical race and class analysis of learning in the organic farming movement. Australian Journal of Adult Learning, 52(3), 484-506.

Flowers, R. (2015). Refusal to forgive: Indigenous women's love and rage. Decolonization: Indigeneity, Education \& Society, 4(2), 32-49.

Fortier, C. (2017a). Unsettling the commons: Social movements within, against, and beyond settler colonialism. Arbeiter Ring Publishing.

Fortier, C. (2017b). Unsettling methodologies/decolonizing movements. Journal of Indigenous Social Development, 6(1), 20-36. 
Gilio-Whitaker, D. (2018, November 14). Settler fragility: Why settler privilege is so hard to talk about. Beacon Broadside. https://www.beaconbroadside.com/broadside/2018/11/settlerfragility-why-settler-privilege-is-so-hard-to-talk-about.html

Gottlieb, R., \& Joshi, A. (2010). Food justice. MIT Press.

Grey, S., \& Newman, L. (2018). Beyond culinary colonialism: Indigenous food sovereignty, liberal multiculturalism, and the control of gastronomic capital. Agriculture and Human Values, 35, 717-730. https://doi.org/10.1007/s10460-018-9868-2

Grey, S., \& Patel, R. (2014). Food sovereignty as decolonization: Some contributions from Indigenous movements to food system and development politics. Agriculture and Human Values, 32(3), 431-444. https://doi.org/10.1007/s10460-014-9548-9

Guthman, J. (2008). "If they only knew": Color blindness and universalism in California alternative food institutions. The Professional Geographer, 60(3), 387-397. https://doi.org/10.1080/00330120802013679

Haiven, M., \& Khasnabish, A. (2013). Between success and failure: Dwelling with social movements in the hiatus. Interface, 5(2), 472-498.

Holt-Giménez, E., Alonso-Fradejas, A., Holmes, T., \& Robbins, M. J. (Eds.). (2018). Food sovereignty: Convergence and contradictions, condition and challenges. Routledge.

Indigenous Action. (2014). Accomplices not allies: Abolishing the ally industrial complex. http://www.indigenousaction.org/accomplices-not-allies-abolishing-the-ally-industrialcomplex/

Indigenous Circle (2009). Discussion paper 1: Indigenous food sovereignty [A People's Food Policy, Food Secure Canada]. https://foodsecurecanada.org/resourcesnews/newsletters/discussion-papers-peoples-food-policy

Jafri, B. (2012). Privilege vs. complicity: People of colour and settler colonialism. Federation for the Humanities and Social Sciences. http://www.ideasidees.ca/blog/privilege-vscomplicity-people-colour-and-settler-colonialism

Jones, A., \& Jenkins, K. (2014). Rethinking collaboration: Working the Indigene-Colonizer hyphen. In N. K. Denzin, Y. S. Lincoln, \& L. T. Smith (Eds.), Handbook of critical and Indigenous methodologies (pp. 471-486). SAGE Publications, Inc. https://dx.doi.org/10.4135/9781483385686

Kamal, A. G., Linklater, R., Thompson, S., Dipple, J., \& Ithinto Mechisowin Committee (2015). A recipe for change: Reclamation of Indigenous food sovereignty in O-Pipon-Na-Piwin Cree Nation for decolonization, resource sharing, and cultural restoration. Globalizations, 12(4), 559-575. https://doi.org/10.1080/14747731.2015.1039761 
Kepkiewicz, L. (2020). Whose land? ACME: An International Journal for Critical Geographies, 19(1), 245-269. Retrieved from https://acmejournal.org/index.php/acme/article/view/1760

Kepkiewicz, L., \& Dale, B. (2018). Keeping 'our' land: Property, agriculture and tensions between Indigenous and settler visions of food sovereignty in Canada. The Journal of Peasant Studies, 46(5), 983-1002. https://doi.org/10.1080/03066150.2018.1439929

Kepkiewicz, L., Chrobok, M., Whetung, M., Cahuas, M., Gill, J., Walker, S., \& Wakefield, S. (2015). Beyond inclusion: Toward an anti-colonial food justice praxis. Journal of Agriculture, Food Systems, and Community Development, 5(4), 99-104. http://dx.doi.org/10.5304/jafscd.2015.054.014

Klein, N. (2013, March 6). Dancing the world into being: A conversation with Idle No More's Leanne Simpson. Yes! Solutions Journal. https:/www.yesmagazine.org/socialjustice/2013/03/06/dancing-the-world-into-being-a-conversation-with-idle-no-moreleanne-simpson/

Kluttz, J., Walker, J., \& Walter, P. (2020). Unsettling allyship, unlearning and learning towards decolonising solidarity. Studies in the Education of Adults, 52(1), 49-66. https://doi.org/10.1080/02660830.2019.1654591

Langton, M. (2006). Earth, wind, fire, and water: The social and spiritual construction of water in Aboriginal societies. In B. David, \& B. Barker (Eds.), The social archaeology of Australian Indigenous societies (pp. 139-160). Aboriginal Studies Press.

Lawrence, B., \& Dua, E. (2005). Decolonizing antiracism. Social Justice, 32(4),120-143.

Levkoe, C. Z. (2014). The food movement in Canada: A social movement network perspective. The Journal of Peasant Studies, 41(3), 385-403. https://doi.org/10.1080/03066150.2014.910766

Levkoe, C., Ray, L., \& Mclaughlin, J. (2019a). The Indigenous Food Circle: Reconciliation and Resurgence through Food in Northwestern Ontario. Journal of Agriculture, Food Systems, and Community Development, 9(B), 101-114. https://doi.org/10.5304/jafscd.2019.09B.008

Levkoe, C. Z., Brem-Wilson, J., \& Anderson, C. R. (2019b). People, power, change: three pillars of a food sovereignty research praxis. The Journal of Peasant Studies, 46(7), 1389-1412.

Lockie, S. (2013). Bastions of white privilege? Reflections on the racialization of alternative food networks. International Journal of Sociology of Agriculture and Food, 23(3), 409418.

Lowman, E. M., \& Barker, A. J. (2015). Settler: Identity and colonialism in $21^{\text {st }}$ century Canada. Fernwood. 
Macoun, A., \& Strakosch, E. (2013). The ethical demands of settler colonial theory. Settler Colonial Studies, 3(4), 426-443. https://doi.org/10.1080/2201473X.2013.810695

Maddison, S., \& Brigg, M. (Eds.). (2011). Unsettling the settler state: Creativity and resistance in Indigenous-Settler state governance. The Federation Press.

Martens, T. (2015). Good news in food: Understanding the value and promise of Indigenous food sovereignty in western Canada [Unpublished master's thesis]. University of Manitoba.

Martens, T. M., Dennis, M. K., \& Hart, M. A. (2020). Feeding Indigenous people in Canada. International Social Work. https://doi.org/10.1177/0020872820916218

Massy, C. (2017). Call of the reed warbler: A new agriculture a new earth. University of Queensland Press.

Mayes, C. (2018). Unsettling food politics: Agriculture, dispossession and sovereignty in Australia. Rowman \& Littlefield International.

McFarlane, P., \& Schabus, N. (2017). Whose land is it anyway? A manual for decolonization. Federation of Post-Secondary Educators of BC. https://fpse.ca/decolonization_manual_whose_land_is_it_anyway

McMurtry, J. (1999). The cancer stage of capitalism. Pluto Press.

Mitchell, R., \& Becker, J. (2019, January 18). Bush food industry booms, but only 1 per cent is produced by Indigenous people. ABC News. https://www.abc.net.au/news/rural/2019-0119/low-indigenous-representation-in-bush-food-industry/10701986

Moreton-Robinson, A. (2015). The white possessive: Property, power, and Indigenous sovereignty. University of Minnesota Press.

Morgan, A. (2019, March 12). Black people in Canada are not settlers. Ricochet. https://ricochet.media/en/2538/black-people-in-canada-are-not-settlers

Morrison, D. (2011). Indigenous food sovereignty: A model for social learning. In H. Witman, A. A. Desmarais, \& N. Wiebe (Eds.), Food sovereignty in Canada: Creating just and sustainable food systems (pp. 97-113). Fernwood.

Morrison, D., \& Brynne, A. (2016). Responsibilities and relationships: Decolonizing the BC Food Systems Network [CFICE Project Report]. Indigenous Food Systems Network and BC Food Systems Network.

https://www.indigenousfoodsystems.org/content/responsibility-and-relationshipsdecolonizing-bc-food-systems-network

Mosby, I. (2013). Administering colonial science: Nutrition research and human biomedical experimentation in Aboriginal communities and residential schools, 1942-1952. Histoire Sociale/Social History, 46(1), 145-172. https://www.muse.jhu.edu/article/512043 
Pascoe, B. (2018). Dark emu: Aboriginal Australia and the birth of agriculture. Scribe Publications.

Pasternak, S. (2017). Grounded authority: The Algonquins of Barriere Lake against the state. University of Minnesota Press.

Patel, R. (2009). Food sovereignty. The Journal of Peasant Studies, 36(3), 663-706. https://doi.org/10.1080/03066150903143079

PFPP [People's Food Policy Project] (2011). Resetting the table: A people's food policy project. Food Secure Canada. https://foodsecurecanada.org/resources-news/blogsdiscussions/peoples-food-policy-project-launched

Phung, M. (2011). Are people of colour settlers too? In A. Mathur, J. Dewar, \& M. DeGagné (Eds.), Cultivating Canada: Reconciliation through the lens of cultural diversity (pp. 289298). Aboriginal Healing Foundation. http://www.ahf.ca/downloads/cultivating-canadapdf.pdf

Regan, P. (2011). Unsettling the settler within: Indian Residential Schools, truth telling, and reconciliation in Canada. UBC Press.

Reynolds, K., Block, D., \& Bradley, K. (2018). Food justice scholar-activism and activistscholarship: Working beyond dichotomies to deepen social justice praxis. ACME: An International E-Journal for Critical Geographies, 17(4), 988-998.

Rose, N. (2021). From the cancer stage of capitalism to the political principle of the common: The Social immune response of "food as commons". International Journal of Health Policy and Management, x(x), 1-11. https://doi.org/10.34172/ijhpm.2021.20

Rotz, S. (2017). 'They took our beads, it was a fair trade, get over it': Settler colonial logics, racial hierarchies and material dominance in Canadian agriculture. Geoforum, 82, 158-169. https://doi.org/10.1016/j.geoforum.2017.04.010

Rudolph, K. R., \& McLachlan, S. M. (2013). Seeking Indigenous food sovereignty: Origins of and responses to the food crisis in northern Manitoba, Canada. Local Environment, 18(9), 1079-1098. https://doi.org/10.1080/13549839.2012.754741

Sbicca, J. (2015). Food labor, economic inequality, and the imperfect politics of process in the alternative food movement. Agriculture and Human Values, 32(4), 675-687. https://doi.org/10.1007/s10460-015-9582-2

Simpson, A. (2014). Mohawk interruptus: Political life across the borders of settler states. Duke University Press

Sium, A., Desai, C., \& Ritskes, E. (2012). Towards the 'tangible unknown’: Decolonization and the Indigenous future. Decolonization: Indigeneity, Education \& Society, 1(1), I-XIII. https://jps.library.utoronto.ca/index.php/des/article/view/18638 
Slocum, R. (2007). Whiteness, space and alternative food practice. Geoforum, 38(3), 520-533. https://doi.org/10.1016/j.geoforum.2006.10.006

Smith, A. (2014). Native studies at the horizon of death: Theorizing ethnographic entrapment and settler self-reflexivity. In A. Simpson \& A. Smith (Eds.), Theorizing Native studies (pp. 207-234). Duke University Press.

Smylie, J. (2021). Our health counts Thunder Bay. Anishnawbe Mushkiki. http://www.welllivinghouse.com/what-we-do/projects/our-health-counts-thunder-bay/

Snelgrove, C., Dhamoon, R. \& Corntassel, J. (2014). Unsettling settler colonialism: The discourse and politics of settlers, and solidarity with Indigenous nations. Decolonization: Indigeneity, Education \& Society, 3(2), 1-32.

Snyder, J. R. (2019). Should transitional justice promote forgiveness?: Insights from Guatemala's recovery of historical memory project. Journal for Peace and Justice Studies, 29(1), 3-23.

Statistics Canada (2017). Focus on geography series, 2016 census. Statistics Canada Catalogue no. 98-404-X2016001. Ottawa, ON. https://www12.statcan.gc.ca/censusrecensement/2016/as-sa/fogs-spg/Facts-CMAEng.cfm?TOPIC $=9 \& \mathrm{LANG}=$ Eng $\& \mathrm{GK}=\mathrm{CMA} \& \mathrm{GC}=595$

Tilzey, M. (2019). Food democracy as 'radical' food sovereignty: Agrarian democracy and counter-hegemonic resistance to the neo-imperial food regime. Politics and Governance, 7(4), 202-213. http://dx.doi.org/10.17645/pag.v7i4.2091

Townsend, M., Phillips, R., \& Aldous, D. (2009). "If the land is healthy... it makes the people healthy": The relationship between caring for Country and health for the Yorta Yorta Nation, Boonwurrung and Bangerang Tribes. Health \& Place, 15(1), 291-299.

Tuck, E. \& Yang, K. W. (2012). Decolonization is not a metaphor. Decolonization: Indigeneity, Education \& Society, 1(1), 1-40. https://jps.library.utoronto.ca/index.php/des/article/view/18630

Veracini, L. (2010). Settler colonialism: A theoretical overview. Palgrave Macmillan.

Wallace, R. (2013). Merging fires: Grassroots peacebuilding between Indigenous and nonIndigenous Peoples. Hignell Book Printing.

Whyte, K. (2018). Food sovereignty, justice and Indigenous Peoples: An essay on settler colonialism and collective continuance. In A. Barnhill, M. Budolfson, \& T. Doggett (Eds.), The Oxford handbook of food ethics (pp. 345-366). Oxford University Press.

Winne, M. (2010). Food rebels, guerrilla gardeners, and smart-cookin' mamas: Fighting back in an age of industrial agriculture. Beacon Press. 
Wolfe, P. (2006). Settler colonialism and the elimination of the native. Journal of Genocide Research, 8(4), 387-409. https://doi.org/10.1080/14623520601056240 